\title{
FAKTOR-FAKTOR YANG MEMPENGARUHI NIAT DAN KEPUTUSAN KONSUMEN MEMBELI SAYURAN DAN BUAH SECARA ONLINE
}

\author{
THE INFLUENCING FACTORS OF COSTUMER INTENTION \\ AND DECISION IN PUSCHASING OF VEGETABLES AND FRUITS BY ONLINE
}

\author{
*Esi Asyani Listyowati, Any Suryantini, Irham \\ Fakultas Pertanian, Magister Manajemen Agribisnis, Universitas Gadjah Mada
}

Submitted: 16-12-2018; Revised: 13-11-2019; Accepted: 17-05-2020

\begin{abstract}
Compared to other goods, online trading on fresh agricultural products such as vegetables and fruit is still relatively new for the Indonesian people. What drives this growing interest in purchasing agricultural products online? This study aims to examine the factors influence consumers' intentions in purchasing vegetables and fruit online and further analyzes the influence of purchase intentions on consumers' decision to make the purchases online. The study was based on analysis of 146 users of online vetabales stores in various more than 10 online platfom accessible in Indonesia from July to August 2018. Users are aged from 15 to more than 54 years. Using seven exogenous latent variables predicted to influence purchase intentions, this study found four variables which proved to influence purchasing intentions, namely perceived usefulness, perceived price, income, and electronic word of mouth. Three variables were perceived ease of use, trust, and perceived risk prevention does not affect the purchase intention. The purchase intention as the first endogenous latent variable proved to influence consumer purchasing decisions as the second endogenous latent variable.
\end{abstract}

Keywords: Online Purchasing; Partial Least Square; Purchasing Decision; Purcasing Intention.

\begin{abstract}
ABSTRAK
Perdagangan online produk masih cukup baru bagi masyarakat Indonesia terutama produk pertanian segar seperti sayuran dan buah sehingga konsumen memiliki beberapa pertimbangan hingga akhirnya memutuskan untuk membeli produk secara online. Penelitian ini bertujuan untuk mengkaji faktor-faktor yang mempengaruhi niat konsumen dalam membeli sayuran dan buah secara online kemudian dianalisis pengaruh niat pembelian terhadap keputusan pembelian konsumen. Metode analisis data penelitian menggunakan Partial Least Square (PLS) dengan tingkat kepercayaan 95\%. Penelitian dilakukan pada bulan Juli hingga Agustus 2018 dengan populasi penelitian merupakan individu yang menggunakan internet di seluruh wilayah Indonesia. Sampel sebanyak 146 diambil secara purposive sampling yaitu individu yang pernah membeli sayuran dan buah secara online dari berbagai aplikasi terhubung internet dengan rentang usia sampel yaitu 15 hingga lebih dari 54 tahun. Tujuh variabel laten eksogen diprediksi mempengaruhi niat pembelian. Hasil penelitian menunjukkan terdapat empat variabel yang terbukti berpengaruh terhadap niat pembelian yaitu persepsi kemanfaatan, persepsi harga, pendapatan,
\end{abstract}

${ }^{*}$ Corresponding author: esiasyani@gmail.com

Copyright@ 2020 THE AUTHOR (S). This article is distributed under a Creative Commons Attribution-ShareAlike 4.0 International license. Jurnal Kawistara is published by the Graduate School of Universitas Gadjah Mada. 
dan getok tular elektronik. Tiga variabel lainnya yaitu persepsi kemudahan, kepercayaan, dan persepsi risiko tidak berpengaruh terhadap niat pembelian. Niat pembelian sebagai variabel laten endogen pertama terbukti mempengaruhi keputusan pembelian konsumen sebagai variabel laten endogen kedua.

Kata kunci: Keputusan pembelian; Niat pembelian; Partial least square; Pembelian online.

\section{PENGANTAR}

Internet merupakan salah satu teknologi modern yang saat ini banyak dimanfaatkan dunia perdagangan. Nugroho (2016) menjelaskan pemanfaatan media elektronik terhubung internet dalam perdagangan disebut dengan electronic commerce (e-commerce). Pada awalnya e-commerce lebih banyak dimanfaatkan untuk menjual barang, seperti fashion, kosmetik dan obat, produk elektronik, jasa travel, dan peralatan rumah. Akan tetapi saat ini $e$-commerce sudah merambah pada penjualan produk pertanian segar seperti sayuran dan buah. Hal tersebut dilatarbelakangi oleh melimpahnya produk pertanian di Indonesia dan adanya keinginan pelaku e-commerce membantu petani memasarkan produk sayuran dan buah langsung kepada konsumen, sehingga harga jual sayuran dan buah tidak dimonopoli oleh para tengkulak. Dengan menjual sayuran dan buah secara online maka akan menguntungkan baik petani maupun pembeli yaitu harga jual bagi petani tidak terlalu rendah seperti ketika menjual pada tengkulak dan harga beli bagi pembeli tidak terlalu tinggi seperti ketika produk sayuran dan buah melewati rantai pemasaran yang panjang (8villages, 2017).

Jual beli online yang kini menjadi tren disebabkan oleh beberapa alasan yaitu informasi produk tersedia lebih rinci, lebih mudah membandingkan kualitas dan harga antar toko, proses pencarian informasi dan pembelian lebih nyaman karena dapat dilakukan dimanapun dan kapanpun (Lestari, 2017). Meskipun adanya keuntungan tersebut, konsumen tetap memiliki pertimbangan untuk melakukan pembelian atau tidak melakukan pembelian secara online.
Persepsi konsumen terhadap penggunaan teknologi menjadi pertimbangan untuk melakukan belanja online. Apakah teknologi yang digunakan bermanfaat dan mudah dioperasikan atau tidak. Jika konsumen memiliki kedua persepsi tersebut maka kemungkinannya konsumen akan melakukan pembelian, begitu pula sebaliknya. Yeo dkk (2017) menjelaskan bahwa persepsi kemanfaatan bagi pembeli yaitu dengan teknologi tertentu akan membantu meningkatkan produktivitas belanja sedangkan kemudahan penggunaan teknologi adalah betapa mudahnya proses menggunakan media baru saat berbelanja di website.

Chen dan Chou (2012) menjelaskan bahwa pada pasar perdagangan elektronik yang populer saat ini syarat dengan risiko, sehingga transaksi hanya dapat dilakukan berdasarkan tingkat kepercayaan tertentu. Meskipun kepercayaan merupakan kunci dalam belanja online, namun tetap memiliki keterbatasan yaitu tidak dapat secara langsung menyentuh dan menilai produk membuat belanja online memiliki risiko yang tinggi. Konsumen merasa khawatir produk yang dipesan tidak sesuai dengan yang ditawarkan sehingga konsumen mengurungkan niatnya untuk membeli.

Pada belanja online harga menjadi terstandar karena informasi produk mudah didapat, sehingga individu atau perusahaan yang menjual produknya secara online harus menjaga agar harga yang ditawarkan tidak melebihi harga pesaing. Kotler dan Keller (2009) menjelaskan harga menjadi faktor utama yang mempengaruhi pilihan para pembeli dan menggunakan harga sebagai indikator kualitas. Belanja online yang konsumen lakukan juga dibatasi oleh pendapatannya, mengingat adanya biaya untuk kebutuhan lain. Tingkat konsumsi konsumen terhadap suatu prouduk dipengaruhi oleh besar kecilnya pendapatan. Semakin tinggi pendapatan yang mereka peroleh, semakin tinggi pula tingkat konsumsi yang mereka lakukan (Janitra dan Pramudana, 2016).

Internet memberi manfaat yang sangat besar dalam penyebaran informasi. Berbagai ulasan atau komentar individu terhadap suatu produk banyak ditemukan di berbagai 
media online. Informasi yang tersebar melalui media terhubung internet (media online) menjadi rerefensi terpercaya bagi konsumen untuk membeli atau tidak karena biasanya informasi tersebut ditulis oleh konsumen yang telah menggunakan produk. Fenomena ini dikenal dengan istilah getok tular elektronik. Theory of Reasoned Action (TRA) menjelaskan bahwa perilaku dilakukan karena individual mempunyai niat atau keinginan untuk melakukannya (Jogiyanto, 2008). Niat beli adalah tahap kecenderungan responden untuk bertindak sebelum benar-benar melakukan pembelian.

Berdasarkan pertimbangan-pertimbangan tersebut, untuk membantu individu atau perusahaan yang secara online menjual sayuran dan buah dapat memahami perilaku konsumen maka penelitian ini hadir dengan tujuan untuk mengetahui ada atau tidaknya pengaruh dari persepsi kemanfaatan, persepsi kemudahan, kepercayaan, persepsi risiko, persepsi harga, pendapatan, dan getok tular elektronik terhadap niat pembelian sayuran dan buah secara online yang selanjutnya akan dianalisis lebih jauh apakah niat pembelian berpengaruh terhadap keputusan pembelian sayuran dan buah secara online.

Penelitian dilaksanakan pada bulan Juli hingga Agustus 2018 dengan populasi penelitian merupakan individu yang menggunakan internet atau media online di seluruh wilayah Indonesia. Ghozali dan Latan (2014) menjelaskan bahwa penentuan jumlah sampel dengan analisis Partial Least Square-Structural Equation Model (PLS-SEM) tidak menuntut jumlah sampel yang besar, minimal jumlah sampel yang direkomendasikan antara 30100. Oleh sebab itu, dalam penelitian ini ditentukan sampel sebanyak 146 responden yang diambil secara purposive sampling dimana kriterianya merupakan individu yang pernah membeli sayuran dan buah pada penjual online minimal satu kali dari berbagai aplikasi terhubung internet. Rentang usia sampel dari 15 tahun hingga lebih dari 54 tahun. Penjual online yang dimaksud adalah individu atau perusahaan yang menjual sayuran dan buah melalui media online baik dalam bentuk pesan terhubung internet seperti whatsApp, line, blackberry massanger, e-mail, dan lainlain, media sosial terhubung internet seperti facebook, instagram, kaskus, twitter, dan lainlain, serta toko online yang memiliki situs jual beli resmi seperti Sayurbox.com, Brambang. com, Keranjangsayur.com, Regopantes.com, Limakilo.id, Tanihub.com, Kecipir.com, dan lain-lain. Data penelitian merupakan data primer yang dikumpulkan melalui survei kuesioner dengan memanfaatkan google form karena peneliti tidak bertemu langsung dengan responden.

Metode analisis data yang digunakan adalah Partial Least Square-Structural Equation Model (PLS-SEM). PLS-SEM merupakan salah satu jenis SEM berbasis varian yang bertujuan untuk menguji hubungan prediktif antar konstruk dengan melihat ada atau tidaknya pengaruh antar konstruk tersebut. Prosedur pertama dalam PLS-SEM adalah mengevaluasi diagram jalur dengan melihat nilai loading factor indikator yang harus lebih besar dari 0,5. Nilai loading factor yang kurang dari 0,5 harus dihilangkan. Kedua, melakukan uji validitas untuk memastikan bahwa pengukur yang digunakan benar-benar mengukur apa yang hendak diukur. Caranya dengan melihat nilai average varian extracted (AVE) yang harus lebih besar dari 0,5. Ketiga, uji reliabilitas komposit untuk mengetahui keakuratan, kekonsistenan, dan ketepatan data penelitian. Data penelitian yang memenuhi uji reliabilitas komposit yaitu yang nilainya lebih besar dari 0,7. Keempat, analisis faktor-faktor yang mempengaruhi niat dan keputusan konsumen dalam membeli sayuran dan buah secara online dilakukan dengan membandingkan nilai t-statistik dengan nilai t-tabelnya. Nilai t-tabel yang digunakan pada penelitian ini adalah 1,96 pada tingkat kepercayaan 95\%. Jika nilai t-statistik variabel laten lebih besar dari 1,96 maka terbukti ada pengaruh yang signifikan dari antar variabel laten yang diuji.

\section{PEMBAHASAN}

Hasil evaluasi diagram jalur penelitian menunjukkan bahwa seluruh nilai loading factor indikator nilainya lebih dari 0,5 . Hasil 
tersebut menunjukkan bahwa indikator dapat digunakan sebagai pengukur variabel latennya sehingga dapat dilakukan uji data selanjutnya. Hasil evaluasi diagram jalur tersedia pada gambar 1. Validitas data yang diukur berdasarkan nilai average variance extracted (AVE) menunjukkan bahwa seluruh nilai AVE variabel laten lebih dari 0,5 sehingga data yang digunakan valid. Nilai reliabilitas komposit seluruh variabel laten juga lebih dari 0,7 sehingga data penelitian yang digunakan dapat dikatakan reliabel (akurat, konsisten, dan tepat). Nilai AVE dan reliabilitas komposit data penelitian disajikan pada tabel 1 .

Tabel 1

Nilai AVE dan Reliabilitas Komposit

\begin{tabular}{llll}
\hline \multicolumn{1}{c}{ Variabel Laten } & & AVE & Reliabilitas Komposit \\
\hline Persepsi Kemanfaatan & 0.547 & 0.878 \\
Persepsi Kemudahan & 0.734 & 0.943 \\
Kepercayaan & 0.767 & 0.929 \\
Persepsi Risiko & 0.716 & 0.926 \\
Persepsi Harga & 0.531 & 0.845 \\
Pendapatan & 0.635 & 0.874 \\
Getok Tular Elektronik & 0.720 & 0.911 \\
Niat Pembelian & 0.749 & 0.899 \\
Keputusan Pembelian & 0.626 & 0.826 \\
\hline
\end{tabular}

Sumber: Analisis Data Primer 2018

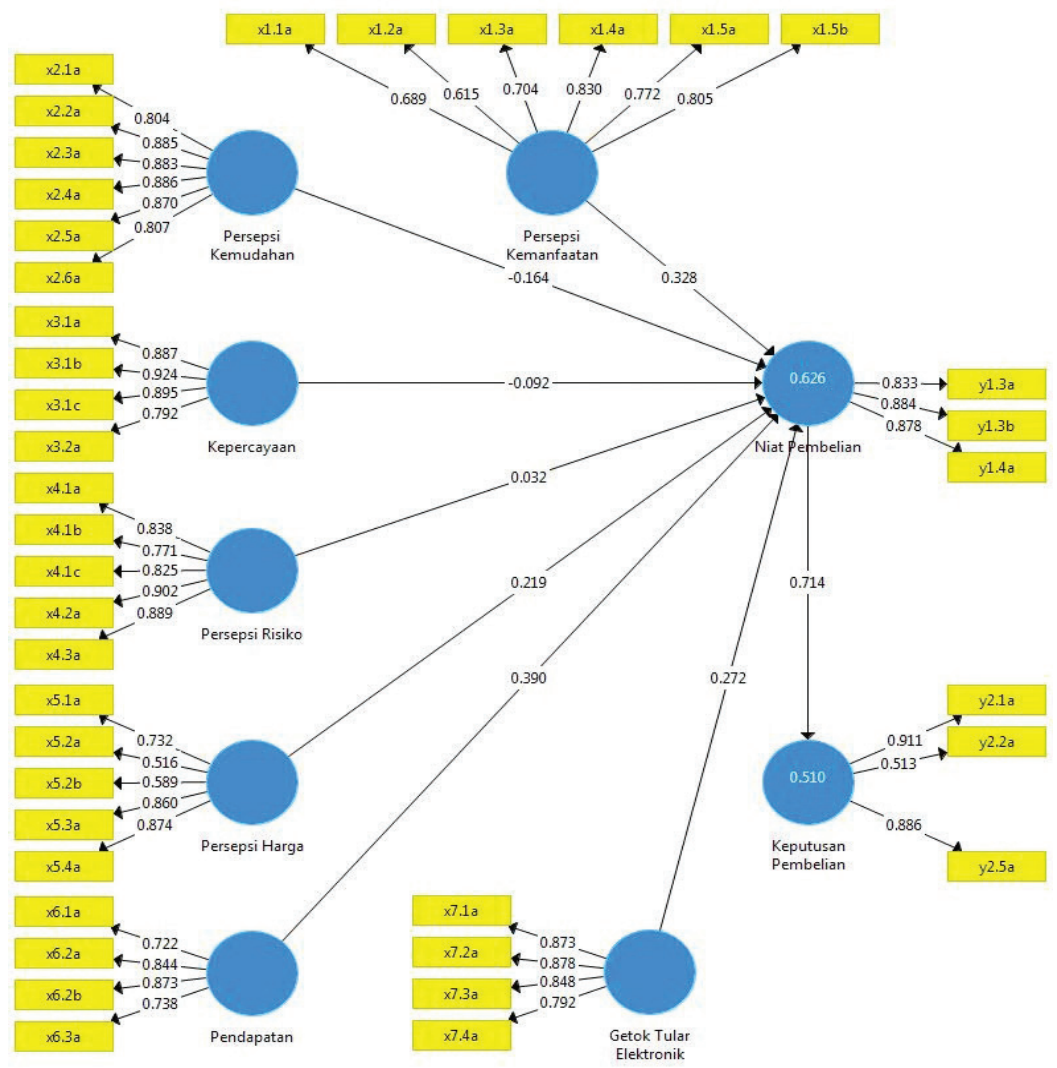

Gambar 1

Hasil Evaluasi Diagram Jalur Penelitian 
Hasil analisis faktor-faktor yang mempengaruhi niat dan keputusan konsumen dalam membeli sayuran dan buah secara online disajikan pada tabel 2. Dari tabel pemaparan hasil penelitian di tabel 2 diketahui bahwa terdapat tiga variabel laten eksogen yang tidak berpengaruh pada niat pembelian karena nilai t-statistiknya tidak lebih dari nilai t-tabel yang ditentukan pada penelitian ini yaitu sebesar 1,96. Tiga variabel laten eksogen tersebut yaitu persepsi kemudahan, kepercayaan, dan persepsi risiko. Sementara itu, terdapat empat variabel laten eksogen yang berpengaruh pada niat pembelian karena nilai t-statistiknya lebih dari 1,96. Empat variabel laten eksogen tersebut yaitu persepsi kemanfaatan, persepsi harga, pendapatan, dan getok tular elektronik. Niat pembelian sebagai variabel laten endogen pertama terbukti berpengaruh pada keputusan pembelian sebagai variabel laten endogen kedua.

Tabel 2

Pengaruh antar- Variabel Laten

\begin{tabular}{llll}
\hline \multicolumn{1}{c}{ Jalur } & Koefisien Jalur & T-Statistik & Keterangan \\
\hline Persepsi Kemanfaatan $\rightarrow$ Niat Pembelian & 0,328 & 3,252 & Berpengaruh \\
Persepsi Kemudahan $\rightarrow$ Niat Pembelian & $-0,164$ & 1,532 & Tidak \\
Kepercayaan $\rightarrow$ Niat Pembelian & $-0,092$ & 1,036 & Tidak \\
Persepsi Risiko $\rightarrow$ Niat Pembelian & 0,032 & 0,308 & Tidak \\
Persepsi Harga $\rightarrow$ Niat Pembelian & 0,219 & 2,229 & Berpengaruh \\
Pendapatan $\rightarrow$ Niat Pembelian & 0,390 & 6,666 & Berpengaruh \\
Getok Tular Elektronik $\rightarrow$ Niat Pembelian & 0,272 & 4,383 & Berpengaruh \\
Niat Pembelian $\rightarrow$ Keputusan Pembelian & 0,714 & 15.248 & Berpengaruh \\
\hline
\end{tabular}

Sumber: Analisis Data Primer 2018

\section{Pengaruh Persepsi Kemanfaatan terhadap Niat Pembelian}

Dari pemaparan hasil penelitian di tabel 2 diketahui bahwa persepsi kemanfaatan berpengaruh positif dan signifikan terhadap niat untuk membeli sayuran dan buah secara online. Artinya, meningkatnya persepsi kemanfaatan dari penggunaan media online pada konsumen akan meningkatkan niat konsumen untuk membeli sayuran dan buah secara online. Media online bermanfaat bagi konsumen untuk mencari informasi terkait produk yang dibutuhkan meliputi daftar penjual yang menjual sayuran dan buah secara online, variasi produk sayuran dan buah yang dijual, harga jual produk, produk yang dideskripsikan dalam bentuk tulisan, foto atau video sehingga bisa langsung membandingkan kualitas antar penjual online tanpa harus datang ke lokasi. Hal tersebut menjadi referensi bahan pertimbangan konsumen sebelum memutuskan membeli. Konsumen yang membeli sayuran dan buah secara online mayoritas merupakan wanita yang bekerja sehingga dengan adanya media online konsumen merasakan manfaat menghemat waktu yaitu meskipun sedang bekerja atau tidak sempat belanja secara langsung karena lelah, konsumen tetap dapat memenuhi kebutuhan sayuran dan buahnya. Konsumen merasakan manfaat belanja lebih cepat karena tidak perlu antri dikasir ketika membayar seperti ketika belanja di pasar tradisional maupun supermarket. Konsumen dapat menggunakan jasa transfer bank, menggunakan virtual account, menggunakan kartu kredit, bahkan ada yang menerima pembayaran saat barang sudah diterima (cash on delivery). Kenyamanan sebagai salah satu manfaat yang bisa dirasakan saat berbelanja menggunakan media online sangat diharapkan konsumen. Jika konsumen berbelanja di pasar tradisional, konsumen akan merasakan tempat yang terbuka, bau, dan kotor. Kondisi tersebut dapat membuat konsumen tidak fokus dalam memilih sayuran dan buah. Sementara itu, jika berbelanja di supermarket yang identik dengan 
tempat belanja yang nyaman karena didukung dengan adanya fasilitas pendingin ruangan (air conditioner) dan kebersihan yang selalu terjaga, konsumen tetap menyatakan bahwa membeli sayuran dan buah secara online lebih nyaman. Hal ini disebabkan kenyamanan yang dirasakan adalah konsumen dapat melakukan pembelian darimana saja dan kapan saja sehingga konsumen tidak harus datang ke supermarket.

Gong dkk (2013) dalam penelitiannya juga menemukan bahwa persepsi kemanfaatan menunjukkan dampak yang signifikan terhadap niat belanja online konsumen Cina. Temuan ini menjelaskan berpengaruhnya persepsi kemanfaatan terhadap niat beli online disebabkan pemasar online menyediakan fitur yang dapat meningkatkan efisiensi belanja online, misalnya mekanisme pencarian yang tidak hanya dapat memberikan informasi relevan dan luas tetapi juga memfasilitasi perbandingan produk dan membantu pengguna membuat keputusan terbaik mereka.

\section{Pengaruh Persepsi Kemudahan terhadap Niat Pembelian}

Berdasarkan pemaparan hasil penelitian di tabel 2 diketahui bahwa persepsi kemudahan tidak terbukti berpengaruh terhadap niat untuk membeli sayuran dan buah secara online. Teknologi (media online) memang memberikan kemudahan dalam membeli sayuran dan buah yaitu mudah menemukan produk, mandiri dalam transaksi, mudah memahami sistem pembayaran, hemat tenaga karena tidak perlu mendatangi penjual, bisa dilakukan dimanapun dan kapanpun, serta mudah membuat keputusan untuk membeli. Akan tetapi, penjualan sayuran dan buah secara online masih merupakan hal yang cukup baru bagi masyarakat Indonesia sehingga kemudahan penggunaan media online baru digunakan untuk mencari tahu informasi seputar penjual yang menjual sayuran dan buahnya secara online. Masyarakat sangat senang berselancar di berbagai toko penjual online untuk melihat variasi produk yang dijual, harga produk, dan ulasan produk dari konsumen sebelumnya hingga pada akhirnya mereka tidak memutuskan membeli. Artinya, masyarakat Indonesia belum memanfaatkan aspek kemudahan penggunaan media online untuk melakukan transaksi sayuran dan buah secara online. Gefen dan Straub (2000) menjelaskan bahwa kemudahan dalam menggunakan internet belum tentu menyebabkan konsumen ingin membeli suatu produk secara online, tetapi kemudahan penggunaan internet digunakan untuk mencari informasi dan membandingkan kualitas produk antar toko dan setelah informasi diperoleh keputusan membeli juga belum tentu dilakukan dengan memanfaatkan internet.

\section{Pengaruh Kepercayaan terhadap Niat Pembelian}

Kepercayaan tidak terbukti berpengaruh terhadap niat untuk membeli sayuran dan buah secara online. Hal tersebut disebabkan oleh dua alasan. Pertama, konsumen lebih tertarik pada pengalaman berbelanja online sayuran dan buah karena merupakan cara penjualan yang masih cukup baru di Indonesia. Wilayah pemasarannya saat ini masih dominan di wilayah Jakarta, Bogor, Depok, Tangerang, dan Bekasi (Jabodetabek). Hal ini disebabkan karena penggunaan media online lebih banyak dilakukan oleh masyarakat di wilayah Jabodetabek yang mayoritas penduduknya juga sibuk bekerja. Konsumen tidak terlalu peduli jika penjual online tidak jujur dalam menyampaikan informasi identitas usaha, tidak jujur dalam menyampaikan informasi karakteristik produk, tidak peduli apakah produk yang akan diterima sesuai penawaran atau tidak, bahkan mereka tidak mengerti jika data identitas yang mereka berikan untuk mengirim produk bisa dicuri pihak lain dan disalahgunakan untuk kepentingan tertentu yang dapat mengganggu privasi mereka misalnya menjual data pribadi konsumen pada perusahaan yang sedang melakukan promosi produk. Kedua, alasannya menyebabkan konsumen membeli bukan disebabkan oleh kepercayaannya terhadap penjual online, tetapi konsumen lebih percaya pada rekomendasi pihak lain yaitu keluarga atau teman yang 
menyarankan untuk membeli sayuran dan buah secara online.

Hasil penelitian ini sejalan dengan penelitian Bianchi dan Andrews (2012) yang menemukan bahwa kepercayaan pada vendor online tidak berpengaruh signifikan pada niat belanja online. Alasannya karena tidak adanya jaminan pihak ketiga seperti indikator sertifikasi produk yang diperdagangkan, tidak adanya pernyataan tentang teknologi enkripsi yang digunakan, tidak adanya indikasi visual sistem pembayaran yang aman melalui penggunaan logo atau ikon tertentu. Dalam belanja online konsumen tidak dapat menilai langsung produk maka, jaminan pihak ketiga sangat penting untuk menjamin agar produk yang diterima sesuai dengan deskripsi penjual online. Konsumen juga sangat berhati-hati dalam belanja online karena identitas pribadi digunakan dalam proses transaksi sehingga konsumen sangat menghendaki tingkat keamanan yang baik agar data pribadinya terlindungi atau tidak disalahgunakan oleh pihak-pihak yang tidak bertanggung jawab.

\section{Pengaruh Persepsi Risiko terhadap Niat Pembelian}

Persepsi risiko tidak terbukti berpengaruh terhadap niat untuk membeli sayuran dan buah secara online. Tidak berpengaruhnya persepsi risiko pada niat pembelian disebabkan lokasi konsumen dengan penjual online mudah dijangkau. Infrastruktur yang memadai membuat pihak jasa pengiriman barang yang bermitra dengan penjual online mampu mengirim produk sesuai batas waktu yang ditentukan agar produk tetap dapat diterima dalam keadaan segar. Pihak jasa pengiriman barang telah mengenal wilayah pemasaran penjual online dengan baik sehingga mudah bagi kurir untuk menemukan alamat konsumen. Selain itu pemanfaatan media komunikasi seperti smartphone mempermudah kurir berkomunikasi dengan konsumen ketika kesulitan menemukan posisi alamat konsumen secara tepat. Konsumen tidak khawatir sayuran dan buah yang diterima tidak sesuai harapan karena penjual online sayuran dan buah akan mengganti produk yang diterima dalam keadaan rusak atau tidak sesuai harapan. Penjual online akan mengganti produk tersebut sesuai yang dipesan sebelumnya atau mengganti dalam bentuk pengembalian uang. Hal ini dilakukan penjual online untuk menjaga citranya di mata konsumen karena konsumen bisa dengan mudah mengungkapkan rasa kecewanya di media online khususnya pada kolom komentar instagram yang lebih sering digunakan untuk mempromosikan produk sehingga konsumen lain bias menilai pelayanan yang diberikan.

Mayoritas konsumen juga sudah pernah membeli sayuran dan buah secara online lebih dari satu kali. Pengalaman konsumen sebelumnya dalam belanja online sayuran dan buah telah mengembangkan basis pengetahuan pada konsumen mengenai kemampuan penjual online untuk dapat memenuhi harapan pembeli atas produk yang dipesan. Informasi yang konsumen peroleh melalui media online juga telah memberi pengetahuan pada konsumen untuk memilih penjual online yang diperkirakan mampu memenuhi pesanan mereka sehingga dapat menghapus kekhawatiran atau risiko ketika membeli sayuran dan buah secara online. Hasil penelitian ini sejalan dengan penelitian yang dilakukan oleh Leeraphong dan Mardjo (2013) yang menemukan peningkatan pengalaman belanja online menyebabkan pengurangan berbagai jenis risiko yaitu risiko produk dan risiko keuangan saat berbelanja online produk non-digital. Khan dan Rizvi (2011) juga menjelaskan bahwa tidak ada hubungan antara risiko dan niat untuk berbelanja secara online karena sebelum berbelanja konsumen telah akrab dengan teknologi sehingga dapat memanfaatkan teknologi untuk mencari informasi terkait produk.

\section{Pengaruh Persepsi Harga terhadap Niat Pembelian}

Hasil penelitian di tabel 2 diketahui bahwa persepsi harga terbukti berpengaruh terhadap niat untuk membeli sayuran dan buah secara online. Artinya, meningkatnya persepsi yang baik konsumen terhadap harga sayuran dan buah yang ditawarkan secara 
online akan meningkatkan niat konsumen untuk membeli sayuran dan buah yang dijual secara online. Konsumen menjelaskan bahwa yang menyebabkan mereka membeli sayuran dan buah secara online karena harganya sesuai dengan daya beli mereka, sesuai dengan kualitas dan manfaat yang akan mereka terima. Membeli sayuran dan buah melalui media online juga sekaligus dapat membandingkan harga antar penjual baik antar penjual online maupun harga di pasar tradisional dan supermarket sehingga membuat konsumen dapat menemukan harga terbaik menurut mereka.

Pada umumnya konsumen juga cenderung memilih harga yang murah dalam setiap membeli produk. Meskipun pada kenyataannya harga sayuran dan buah yang dijual secara online lebih mahal daripada harga di pasar tradisional namun, konsumen tetap membeli secara online. Hal ini disebabkan penjual online terus berusaha membuat harga jualnya bisa dianggap murah oleh konsumen biasanya dilakukan dengan pemberian potongan harga untuk pembelian dengan nominal tertentu, bebas biaya pengiriman dengan nominal pembelian tertentu, promo penjualan di waktu-waktu tertentu atau flash sale yaitu diskon yang diberikan dalam waktu singkat. Melalui beberapa strategi harga inilah yang menyebabkan konsumen memiliki persepsi harga yang baik pada sayuran dan buah yang dijual secara online. Pendapat yang sama dari hasil penelitian Yeo dkk (2017) menemukan bahwa dengan adanya internet akan memberi kemudahan bagi konsumen untuk membandingkan harga sehingga menjadi salah satu faktor yang berpengaruh dalam menciptakan niat untuk membeli secara online.

\section{Pengaruh Pendapatan terhadap Niat Pembelian}

Berdasarkan tabel 2 diketahui bahwa pendapatan terbukti berpengaruh terhadap niat konsumen. Hasil ini menunjukkan bahwa dengan meningkatnya pendapatan konsumen maka niat untuk membeli sayuran dan buah secara online juga meningkat. Pada penelitian ini pendapatan berpengaruh pada niat membeli sayuran dan buah secara online meskipun kenaikan pendapatan diutamakan untuk meningkatkan belanja sayuran dan buah di pasar tradisional dan supermarket. Selain itu, pendapatan yang dialokasikan untuk membeli sayuran dan buah baik di pasar tradisional, supermarket maupun secara online juga sebanding. Hal ini disebabkan karena mayoritas konsumen yang membeli sayuran dan buah secara online memiliki tingkat pendapatan yang tinggi yaitu lebih dari Rp 5.000.000 per bulan. Mereka tidak keberatan membayar mahal sayuran dan buah yang dijual secara online karena pada saat yang sama mereka memiliki kesibukan lain yang lebih penting. Mayoritas pertama konsumen merupakan wanita yang bekerja dan mayoritas kedua merupakan konsumen yang memiliki bayi dan balita sehingga membuat mereka tidak dapat membeli sayuran dan buah secara langsung di pasar tradisional atau supermarket. Oleh sebab itu, mayoritas konsumen setuju bahwa pendapatan yang diterima memungkinkan untuk membeli sayuran dan buah secara online. Punj (2012) memperjelas hal tersebut dengan hasil temuan yang sama bahwa konsumen dengan tingkat pendapatan tinggi cenderung akan membeli secara online karena mereka tidak harus menghabiskan waktu pergi ke toko dan mengantri saat hendak membayar. Menurut mereka waktu lebih berharga daripada uang yang mereka keluarkan untuk berbelanja.

\section{Pengaruh Getok Tular Elektronik terhadap Niat Pembelian}

Getok tular elektronik terbukti berpengaruh positif terhadap niat pembelian, sehingga dapat dikatakan bahwa dengan meningkatnya aktivitas getok tular elektronik akan meningkatkan niat konsumen untuk membeli sayuran dan buah secara online. Tiga indikator penting dari variabel getok tular elektronik yaitu membaca ulasan online positif, membaca rekomendasi online serta ulasan, dan rekomendasi meningkatkan keyakinan untuk membeli disetujui oleh konsumen sebagai indikator yang mempengaruhi niat membeli sayuran dan buah secara online, meskipun 
tidak mengharuskan dirinya untuk mengirim komentar setelah memiliki pengalaman membeli sayuran dan buah secara online. Oleh karena itu, sangat perlu bagi penjual online untuk menjaga agar ulasan tentang mereka yang beredar di media online merupakan halhal yang positif sehingga konsumen yang telah membeli produk dapat merekomendasikan pada pihak lain untuk ikut membeli.

Membeli produk dengan layanan tidak berwujud membawa risiko lebih tinggi daripada membeli produk secara langsung, sehingga konsumen berusaha mengurangi risiko tersebut. Salah satu caranya adalah dengan mencari tahu berbagai informasi produk yang akan dibeli melalui komentar atau review produk dari pemakai sebelumnya pada media terhubung internet. Jenis komunikasi ini dianggap memiliki persuasi yang sangat baik dan lebih terpercaya daripada iklan pemasar karena disampaikan langsung oleh pemakai atau konsumen sebelumnya (Chevalier dan Mayzlin, 2006). Di era media sosial seperti saat ini, pola perilaku konsumen adalah AISAS (Attention-Interest-Search-Action-Share). Dengan kata lain, faktor yang juga penting mempengaruhi niat membeli konsumen adalah pengalaman konsumsi konsumen yang dibagikan melalui komentar online di media sosial. Pengalaman tersebut memberi konsumen referensi informasi dan bukti kuat untuk evaluasi keputusan pembelian yang telah dilakukan (Zhou, 2017).

\section{Pengaruh Niat Pembelian terhadap Keputusan Pembelian}

Niat pembelian sebagai variabel laten endogen pertama berpengaruh terhadap keputusan pembelian sebagai variabel laten endogen kedua, artinya dengan meningkatnya niat konsumen untuk membeli sayuran dan buah secara online akan berdampak pada meningkatnya keputusan konsumen untuk melakukan pembelian sayuran dan buah secara online. Pada penelitian ini diketahui bahwa konsumen yang berkeinginan membeli menunjukkan niatnya dengan mengeksplorasi informasi yang dibutuhkan sebagai bahan pertimbangan untuk membeli, merencanakan pembelian dalam waktu dekat, tetapi tidak mengharuskan dirinya mengajak orang lain untuk ikut membeli. Konsumen yang memiliki niat membeli sayuran dan buah secara online juga masih membeli sayuran dan buah di pasar tradisional dan supermarket karena membeli secara online merupakan solusi cara pembelian ketika konsumen terkendala waktu untuk membeli secara langsung.

Sejalan dengan penelitian Rahmaningtyas dkk (2017) berhasil membuktikan bahwa niat pembelian makanan khas daerah secara online berpengaruh positif terhadap keputusan pembelian makanan khas daerah secara online. Individu yang mempunyai niat membeli memiliki kemungkinan lebih besar untuk melakukan transaksi pembelian. Sesuai dengan Theory of Reasoned Action (TRA) yang dijelaskan oleh Jogiyanto (2008) bahwa perilaku dilakukan karena individual mempunyai niat atau keinginan untuk melakukannya (behavioral intention).

\section{SIMPULAN}

Terdapat beberapa implikasi dari penelitian ini yang memberikan arahan pada penjual online sayuran dan buah. Pertama, dari aspek kemanfaatan penggunaan teknologi, konsumen telah merasakan manfaat dari media online dalam belanja online sehingga sebaiknya penjual online dapat terus mempertahankan apa yang telah dicapai tersebut. Kedua, dari aspek kemudahan penggunaan teknologi, penjual online hendaknya dapat membuat tampilan website dan aplikasi yang user friendly sehingga konsumen mudah dalam menemukan produk dan melakukan transaksi secara online. Ketiga, dari aspek kepercayaan, hendaknya penjual online dapat membangun kepercayaan pada konsumen untuk membentuk niat membeli sayuran dan buah secara online di tokonya terutama melalui karakteristik produk yang disampaikan secara jujur. Keempat, penjual online dapat mencegah risiko yang dirasakan konsumen saat belanja online sayuran dan buah dengan selalu mengirimkan pesanan sayuran dan buah sesuai dengan harapan konsumen. Kelima, penjual online harus selalu menjaga harga yang ditawarkan sesuai dengan manfaat 
yang diterima konsumen. Keenam, penjual online hendaknya menjaga kepuasan konsumen agar pendapatan yang diperoleh dapat selalu dialokasikan lebih besar untuk membeli sayuran dan buah secara online. Ketujuh, menjaga agar ulasan yang beredar di media online merupakan hal-hal yang positif sehingga konsumen yang telah membeli produk akan menjadi loyal dan dapat merekomendasikan pada pihak lain untuk ikut membeli.

Penelitian dengan tema perdagangan online komoditas pertanian masih jarang dilakukan dan penelitian ini cukup modern, sesuai dengan teknologi yang sedang berkembang, sehingga sangat disarankan bagi para akademisi untuk dapat melakukan penelitian serupa dengan pengembanganpengembangan yang diperlukan.

Meskipun demikian, penelitian ini memiliki keterbatasan yaitu peneliti tidak dapat bertemu langsung dengan responden, sehingga bagi peneliti yang akan melakukan penelitian dengan konsep serupa harus memperhatikan hal-hal berikut. Pertama, sangat disarankan untuk membuat kuesioner yang tidak menyita waktu yaitu menghindari membuat pertanyaan dengan makna yang sama dari pertanyaan yang dibuat sebelumnya dengan waktu pengisian maksimal 10 menit untuk menghindari kebosanan responden saat mengisi kuesioner. Kedua, gunakan kalimat yang efektif dan efisien agar kuesioner lebih mudah dipahami responden. Ketiga, kuesioner harus mudah diisi konsumen sehingga disarankan untuk membuat kuesioner dengan tipe multiple choice.

\section{DAFTAR PUSTAKA}

8villages (2017) Sosialisasi RegoPantes. Indonesia: PT 8villages Indonesia. Tersedia di https://youtu.be/ JqNJWPG7wZE. Diakses pada 28 November 2017.

Bianchi, C. dan L. Andrews. (2012). Risk, Trust, and Consumer Online Purchasing Behaviour: A Chilean Perspective. International Marketing Review, 29(3): 253-275. Doi: $10.1108 / 02651331211229750$.
Chen, Y. dan T. Chou. (2012). Exploring the Continuance Intentions of Consumers for B2C Online Shopping Perspectives of Fairness and Trust. Online Information Review, 36(1): 104-125. Doi: $10.1108 / 14684521211209572$.

Chevalier, J. A. dan D. Mayzlin. (2006). The Effect of Word of Mouth on Sales: Online Book Reviews. Journal of Marketing Research, 43(3): 345-354. doi: 10.1509/jmkr.43.3.345.

Gefen, D. dan D. Straub. (2000). The Relative Importance of Perceived Ease of Use in IS Adoption: A Study of E-Commerce Adoption. Journal of the Association for Information Systems, 1(1): 1-30. Doi: 10.17705/1jais.00008.

Ghozali, I. dan Latan, H. (2014). Partial Least Squares: Konsep, Teknik dan Aplikasi Menggunakan Program SmartPLS 3.0. Semarang: Badan Penerbit Universitas Diponegoro Semarang.

Gong, W., R. L. Stump, dan L. M. Maddox. (2013). Factors Influencing Consumers Online Shopping in China. Journal of Asia Business Studies, 7(3): 214-230. Doi: 10.1108/JABS-022013-0006.

Janitra, I. M. D. P. dan K. A. S. Pramudana. (2016). Pengaruh Variabel Demografi dan Persepsi Kualitas Produk Terhadap Keputusan Pembelian Produk Hijau Philips LED di Kota Denpasar. E-Jurnal Manajemen Unud, 5(8): 5013-5040.

Jogiyanto, H. M. (2008). Sistem Informasi Keperilakuan Edisi Revisi. Yogyakarta: Andi.

Khan, S. dan A. H. Rizvi. (2011). Factors Influencing the Consumers Intention to Shop Online. Skyline Business Journal, 7(1): 28-33.

Kotler, P. dan Keller, K. L. (2009). Manajemen Pemasaran. Jakarta: Erlangga. 
Leeraphong, A. dan A. Mardjo. (2013). Trust and Risk in Purchase Intention through Online Social Network: A Focus Group Study of Facebook in Thailand. Journal of Economics, Business and Management, 1(4): 314318. Doi: 10.7763/joebm.2013.v1.68.

Lestari, S. A. (2017). Analisis Faktor-faktor yang Mempengaruhi Keputusan Belanja Online: PVT Model. Universitas Gadjah Mada.

Nugroho, A. S. (2016). E-Commerce : Teori dan Aplikasinya. Yogyakarta: Ekuilibria.

Punj, G. (2012). Income Effects On Relative Importance of Two Online Purchase Goals: Saving Time Versus Saving Money?. Journal of Business Research. Elsevier Inc., 65(5): 634-640. Doi: 10.1016/j.jbusres.2011.03.003.
Rahmaningtyas, A., S. Hartono, dan A. Suryantini. (2017). Faktor-Faktor Yang Mempengaruhi Pembelian Makanan Khas Daerah Secara Online. Jurnal Agro Ekonomi, 28(2): 189-204.

Yeo, V. C. S., S. K. Goh, dan S. Rezaei. (2017). Consumer Experiences, Attitude and Behavioral Intention Toward Online Food Delivery (OFD) Services. Journal of Retailing and Consumer Services. 35: 150-162. Doi: 10.1016/j. jretconser.2016.12.013.

Zhou, X. Z. S. D. Y. (2017). The Impact of Reference Effects on Online Purchase Intention of Agricultural ProductsThe Moderating Role of Consumers' Food Safety Consciousness. Journal of Internet Research, 27(2). Doi: http:/ / dx.doi.org/10.1108/IntR-032016-0082. 